\title{
TULE TAEVAS APPI, TULGE OMETI RAEKOJA PLATSIST KAUGEMALE KA: KODANIKE TEKSTISTRATEEGILISED VALIKUD AMETIASUTUSE POOLE PÖÖRDUMISEL
}

\author{
RIINA REINSALU
}

\begin{abstract}
Annotatsioon. Tänapäeva infoühiskonna toimimise eeldusi on dialoogiline suhtlus kodanike ja ametnike vahel. Selleks pakuvad ametkonnad mitmesuguseid võimalusi, sh võimalust osutada probleemidele veebivormi vahendusel. Artikli eesmärk on välja selgitada, milliseid tekstistrateegilisi valikuid kodanikud teevad, kui nad pöörduvad ametnike poole kaebuse vormis. Tartu linnavalitsusele esitatud 40 kaebuse analüüsist ilmneb, et kaebuse sisestruktuur põhineb kolmel kohustuslikul käigul: probleemile osutamisel, rahulolematuse väljendamisel ja soovitava teo nimetamisel. Tekstitasandil realiseeruvad need käigud mitmesuguste metatekstuaalsete keelevahenditena, mille hulgas domineerivad sellised, mis võimaldavad väljendada negatiivseid emotsioone.
\end{abstract}

Võtmesõnad: kaebus, ametisuhtlus, tekstitüüp, metadiskursus, žanrianalüüs, eesti keel

\section{Sissejuhatus}

Kodanike ja ametiasutuste kirjalik suhtlus põhineb sotsiaalsetel tavadel üldkehtivatel normidel, mis on kultuuriruumis aja jooksul omaks võetud ja mida vaikimisi järgitakse. Need tavad pole aga jäigalt fikseeritud, vaid on altid muutustele. Näiteks on tehnoloogilise võidukäigu mõjul traditsiooniline paberkiri asendunud enamjaolt e-kirjaga, tuues kaasa muutusi kirja struktuuris. Suhtluse lihtsustamiseks on osa ametiasutusi võtnud kasutusele ka veebivormi, mille struktuur dikteerib kirja ülesehituse, soosides veelgi lakoonilisemat väljendusviisi.

Artiklis võtan vaatluse alla kodanike ja ametiasutuste suhtluse, mis põhineb Tartu linnavalitsuse veebilehe rubriigi „Ametnik vastab“ kaudu 
tehtud pöördumistel. Kuigi veebilehel on märge „Ootame siia rubriiki küsimusi probleemide kohta Tartu linnas“, pole kõik pöördumised siiski küsimuste vormis. Pigem ühendab neid soov juhtida ametnike tähelepanu puudustele, mis annab alust nimetada vaatlusaluseid tekste kaebusteks. Suhtlusolukorra teeb pinevaks ametiasutuse kahetine roll: kuigi ametiasutust peetakse probleemi eest kas otseselt või kaudselt vastutavaks, on tema võimuses ka olukord heastada. Seetõttu võib eeldada, et kodanik on tekstistrateegilisi valikuid tehes ettevaatlik, valides hoolikalt viisi, kuidas ametiasutuse poole pöörduda. See puudutab nii pöördumise sisestruktuuri kui ka kasutatavaid keelevahendeid.

Artikli allikmaterjali moodustab 40 kaebust, mille kodanikud on esitanud Tartu linnavalitsusele heakorra kohta. Juhindudes John Swalesi (1990) Žanriteoreetilisest käsitlusviisist, otsin vastust küsimusele, millistest kohustuslikest ja valikulistest käikudest kaebuste sisestruktuur koosneb. Kaebuste üldeesmärki silmas pidades võib eeldada, et ühe käiguna oodatakse ametnikult mingit tegu, mistõttu kuulub artikli huvialasse, milliste instruktiivsete keelevahendite abil on see tegu vormistatud. Kuna kaebuste esitamise kaudu panevad kodanikud aluse dialoogilisele suhtlusele, siis keskendun artikli teises pooles osaliste suhetele, mis avalduvad Ken Hylandi (2005b) metadiskursiivse raamistiku järgi interaktsiooniliste tunnustena. Eesmärk on välja selgitada vaatlusaluse suhtluskonteksti seisukohalt dominantsed interaktsioonilised keelevahendid.

\section{2. Žanriteoreetiline lähtepunkt}

Kuigi kaebused on kuulunud peamiselt John Searle'ist lähtuva kõneaktiteooria valdkonna uurimuste huviorbiiti (vt nt Olhstain, Weinbach 1993; Trosborg 1995), jätkatakse siinses artiklis John Swalesi koolkonna žanriuuringute suunda. Swalesi žanrikäsitluse järgi on žanr kommunikatiivsete sündmuste kogum, mille seovad tervikuks ühised eesmärgid, mida soovitakse vaatlusaluses sotsiaalses kontekstis saavutada. Need eesmärgid kujundavad žanri sisestruktuuri ning avaldavad mõju nii selle sisule kui ka keelekasutusele. (Swales 1990: 58) Kuna sotsiaalne kontekst hõlmab osalisi, mõjutavad keelekasutust ka osaliste suhted: see, kui hästi tekst oma eesmärki täidab, oleneb tugevalt kirjutaja konteksti- ja lugejateadlikkusest (Hyland 2003: 21). Osalised aga esindavad mõnd sotsiaalset rühma, mistõttu on suhtlusolukord ühtaegu võimusuhete taimelava. Seega 
on žanr justkui kanal, mis ühelt poolt soodustab sotsiaalset suhtlust, kuid teiselt poolt piirab seda, võimaldades suhtlusolukorrast kõrvale tõrjuda need osalised, kes ei tunne žanritavasid või ei panusta suhtlusse piisavalt (Tardy, Swales 2014: 167).

Kuna žanrianalüüs teoreetilise raamistikuna on mitmetahuline, hõlmates peale tekstitasandi ka muid tähendusloome tasandeid, läheb žanrite analüüsimiseks tarvis laialdast meetodite arsenali. Christine Tardy ja John Swales osutavad, et kui diakrooniline žanrianalüüs (ingl diacronical genre analysis) keskendub enamasti mõne üksikžanri sotsiaalajaloolisele muutumisele, siis sünkroonilisest aspektist uuritakse, mil viisil keelekasutajad kohandavad žanrit või kontrastiivselt žanreid (ingl comparative genre analysis) oma vajaduste järgi. Uurimused on valdavalt teksti- või struktuurikesksed (ingl vastavalt text analysis, move (structure) analysis), kuid üha enam lisatakse žanrianalüüsi ka kriitilise diskursuseanalüüsi elemente, mis annab alust rääkida kriitilisest žanrianalüüsist (ingl critical genre analysis). Aja jooksul on laienenud ka uurimisfookus, hõlmates peale kirjalike tekstide näiteks pilte ja muusikat, mida analüüsitakse multimodaalse või visuaalse žanrianalüüsi (ing1 vastavalt multimodal genre analysis, visual genre analysis) raamistikus. (Tardy, Swales 2014: 167-173) Selline nihe kajastub ka John Swalesi (2016: 33) enda hiljutises uurimuses, kus ta on võtnud vaatluse alla teksti ja pildi koosmõju ning varieerinud uurimismeetodeid, sest traditsiooniline struktuurianalüüs on osutunud ebapiisavaks.

Kuigi üha enamates žanriuurimustes on seatud sihiks vähendada tekstikesksust, kombineerides keeleteaduslikke uurimismeetodeid muudega, peamiselt intervjuude ja juhtumiuuringutega (Bhatia 2002: 13), olen siinses artiklis otsustanud jääda siiski struktuurianalüüsi juurde, sest seda on varemgi edukalt rakendatud just kaebuste (ingl letter of complaint) analüüsimisel (vt nt Henry, Ho 2010; Al-Momani 2014). Kuigi teaduskirjanduse põhjal varieerub kaebuste struktuur tugevasti, võib sellegipoolest väita, et mistahes kaebusi seovad enamasti kaks tunnust: vajadus osutada probleemile (esitada kaebus) ja nõue lahendada probleem. Ülejäänud tunnused - Swalesist lähtuva struktuurianalüüsi mõistes käigud (ingl moves) ja sammud (ingl steps) - olenevad situatsiooni- ja kultuurikontekstist. Kontekstisidususest tuleneb ka struktuurianalüüsi rakenduslik väljund, sest konteksti tundmata võib olla keeruline valida sobivat suhtlusstrateegiat. Seetõttu rakendatakse struktuurianalüüsi tulemusi sageli ka žanripõhises 
(võõr)keeleõppes (tervikkäsitlustest vt nt Hyland 2007; Bruce 2008; Hyon 2017).

\section{Metadiskursiivne vaatenurk}

Nii teoreetilis-metoodilistes ülevaadetes kui ka empiirilistes uurimustes on žanripõhist struktuurianalüüsi põimitud metadiskursiivse tekstianalüüsiga. Ken Hyland, kes liigitab metadiskursuse alla interpersonaalsed keelevahendid, mille abil korrastatakse diskursust või mille kaudu suhestub autor kas teksti või lugejaga (Hyland 2005a: 997), peab metadiskursust üheks žanrianalüüsi põhidimensiooniks. Metadiskursiivsete tunnuste kaudu tulevad esile kirjutaja eesmärgid ja oletused, mida ta teeb oma auditooriumi kohta, samuti vastastikmõjulised suhted lugejatega (Hyland 2005b: 89). Seega ei ole metadiskursus sisuloome teenistuses, vaid see võimaldab lugejal paremini teksti jälgida, tõlgendada ja hinnata ning kujundada oma suhtumist sellesse (Vande Kopple 2012: 38). Kuna metadiskursiivsed keelevahendid on oma laadilt subjektiivsed, väljenduvad nende kaudu ka kultuuritavad (Abdi 2002: 140).

Tuginedes William Vande Kopplest (1985) alguse saanud metadiskursiivsele uurimistraditsioonile, mida Annelie Ädel ja Anna Mauranen (2010: 3) nimetavad tugevalt kvantitatiivse suunitluse tõttu nn õhukeseks lähenemisviisiks (ingl thin approach), eristab Ken Hyland metadiskursuse interaktiivset ja interaktsioonilist mõõdet (vt tabel 1). Interaktiivsete tunnuste korral on fookuses kirjutaja teadlikkus lugejaskonnast: kirjutaja eesmärk on anda tekstile selline kuju, mis võimaldaks vastata lugejate vajadustele. Seevastu interaktsiooniliste tunnuste kaudu väljendab kirjutaja oma suhtumist otsesõnu ja kaasab lugejat eksplitsiitselt. (Hyland 2005b: 49) Viis, kuidas kirjutaja võtab endale mingi positsiooni ja suhestab end lugejaga kindlas kontekstis, kasutades metadiskursiivseid keelevahendeid, muudab mõttekäigu lihtsamini jälgitavaks, isiklikumaks ja huvitavamaks (Hyland 2005a: 998).

Pidades silmas artikli fookust ja analüüsitavate tekstide laadi, keskendun siinkohal üksnes interaktsoonilistele tunnustele, nagu seda on tehtud ingliskeelsetes uurimustes kaebuste (kaebekirjade) kohta. Dominantseks uurimisvaldkonnaks selles liinis on kujunenud ärisuhtlus, mille korral on võetud vaatluse alla kas kõik interaktsioonilised tunnused või on piirdutud ühe spetsiifilise kategooriaga. Näiteks on uuritud pehmendavate keelendite 


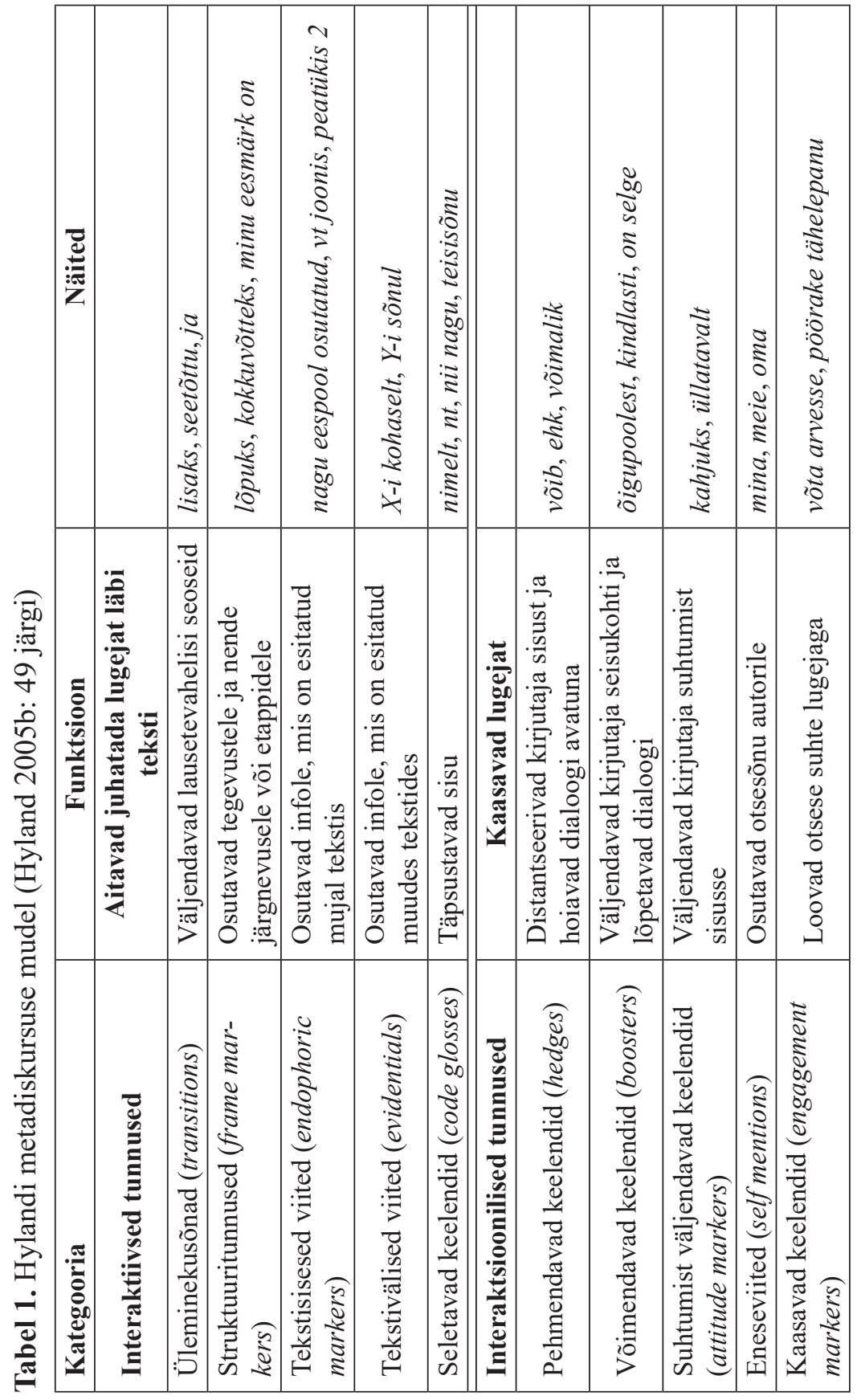


kasutust, et välja selgitada diskursusestrateegiad, mille abil saab muuta kaebuse kergemini loetavaks ja seeläbi luua hea alus läbirääkimisteks (Hooi, Shuib 2014: 123). Niisama tähtis kui see, mis strateegiat kasutatakse kaebuste esitamisel, on ka see, kuidas kaebustele reageeritakse, mistõttu on uurimustes pööratud eritähelepanu ka vastuskirjadele (nt Schaefer 2010). Sellised uurimused on valdavalt praktilise suunitlusega, eeskätt tõhusama (võõr)keeleõppe või erialase suhtluse teenistuses.

\section{Allikmaterjal ja meetod}

Artikli allikmaterjali moodustavad kirjalikud kaebused, millega kodanikud on pöördunud ajavahemikus 18.09.2013-20.09.2017 Tartu linnavalitsuse poole linna veebilehe rubriigi „Ametnik vastab"1 kaudu. Artikli eesmärgist tingituna kuuluvad valimisse üksnes need kaebused, kus kodanik väljendab otsesõnu või kaude rahulolematust linnavalitsuse tegevusega, kuid mitte kaebused naabrite ja teiste linnaelanike tegevuse kohta. Valimist on välja jäänud korduvad kaebused, samuti sellised kaebused, millele ametnik ei olnud allikmaterjali kogumise hetkeks veel vastanud. Kõiki tekste seob üks teema - linna heakord.

Analüüsitavaid kaebusi on kokku 40 kogumahuga 2659 sõna. Lühim kaebus koosneb 7 sõnast ja pikim 199 sõnast. Keskmine pikkus on 67 sõna. Mõnes kaebuses osutatakse, et tekstile on lisatud ka foto, mis annab ülevaate probleemist, kuid linnavalitsuse veebilehel pole need fotod kuvatud. Seega on uurimisobjekt üksnes kirjalik tekst.

Kaebusi analüüsin Swalesi struktuurianalüüsi ja Hylandi metadiskursiivse analüüsi raamistikus kvalitatiivselt, st täpsete arvandmete asemel osutan üksnes peamistele suundumustele. Analüüsitulemusi ilmestavad asjakohased tekstinäited, mis on esitatud muutmata kujul (v.a kursiivkiri, mis on kasutusel esiletõstuvahendina, ja katkestuspunktid, mis märgivad väljajättu). Näidetele on lisatud kaebuse number korpuses.

\section{Kaebuse sisestruktuur}

Struktuurianalüüsi põhjal joonistus välja kolmest kohustuslikust ja neljast valikulisest käigust koosnev struktuuriskeem (vt tabel 2). Analüüsist ilmnes, et kodanikud pöörduvad linnavalitsuse poole eesmärgiga osutada

${ }^{1}$ http://www.tartu.ee/et/ametnik-vastab/lisa-kusimus (01.11.2017). 
probleemile, väljendada kas kaude või otsesõnu oma rahulolematust linnavalitsuse tegevusega ning nimetada tegu, mis on vajalik probleemi kõrvaldamiseks. Kuna need kolm käiku kajastuvad peaaegu kõigis vaatlusalustes tekstides, võib neid pidada nende olemuslikeks tunnusjoonteks. Harvem, valikuliste käikudena peavad kodanikud vajalikuks esitada olukorra neutraalne kirjeldus, mida mõnel juhul toetatakse ka fotodega sündmuskohast, ning tutvustada pöördumise tausta, näidates oma seotust probleemiga. Suhtlusolukorra kujundamine viisakusavaldustega pöördumise alguses ja lõpus on omane vaid üksikutele tekstidele.

Tabel 2. Tekstistrateegilised valikud

\begin{tabular}{|c|c|}
\hline $\begin{array}{l}\text { Tekstistrateegilised } \\
\text { valikud }\end{array}$ & Näited \\
\hline \multicolumn{2}{|l|}{ Kohustuslikud käigud } \\
\hline Probleemile osutamine & $\begin{array}{l}\text { Pea aasta aega on Tartu avaturul jõepoolses } \\
\text { väravas ja lillepoe ees räuskavad, suitsetavad, } \\
\text { ropendavad, prahti maha loopivad noored. }\end{array}$ \\
\hline $\begin{array}{l}\text { Rahulolematuse } \\
\text { väljendamine }\end{array}$ & $\begin{array}{l}\text { Kas on lootust, et midagi hakkab muutuma?; } \\
\text { Selline käitumine pole ju avalikus linnaruumis } \\
\text { aksepteeritav. }\end{array}$ \\
\hline $\begin{array}{l}\text { Soovitava teo } \\
\text { nimetamine }\end{array}$ & $\begin{array}{l}\text { Kas omanikke on teavitatud puu ohtlikkusest?; } \\
\text { Palun Kastani } 133 \text { krundi omaniku kontakti. }\end{array}$ \\
\hline \multicolumn{2}{|l|}{ Valikulised käigud } \\
\hline $\begin{array}{l}\text { Suhtlusolukorra } \\
\text { loomine }\end{array}$ & Tere!; Lp linnavalitsuse ametnik \\
\hline Tausta tutvustamine & $\begin{array}{l}\text { Helistasin heakorra lühitelefonil, aga sellest abi } \\
\text { ei olnud. }\end{array}$ \\
\hline Olukorra kirjeldamine & $\begin{array}{l}\text { Õhtuti, peale tööd, pargivad autod osaliselt } \\
\text { kõnniteedel ja ristmikele väga lähedal. } \\
\text { Jalakäijatel pole võimalik kõnniteed kasutada. }\end{array}$ \\
\hline $\begin{array}{l}\text { Suhtlusolukorra } \\
\text { lõpetamine }\end{array}$ & Lugupidamisega; Tänan \\
\hline
\end{tabular}

Kuigi kaebuste sisestruktuuris võib eristada kohustuslikke ja valikulisi käike, ei ilmne selget mustrit nende järjekorras. Vaid pöördumistes, kus kirjutaja panustab suhtlusolukorra kujundamisse, moodustavad kasutatud algus- ja lõpuvormelid pöördumise raami (näide 1). Muudel juhtudel on käikude järjekord vaba, olenedes kirjutaja eelistustest. 
(1) Tere,

Sellel kevad-suve hooajal ei ole veel kordagi niidetud heina Tartus Vindi tn 3. Kuna hooldatakse või niidetakse maha "mehekõrgune" hein Vindi tn 3 krundil?

Tänan (K25)

Peale selle, et käikude järjekord varieerub suuresti, on vaatlusalustele kaebustele iseloomulik ka tähenduslike tekstiüksuste mitmefunktsioonilisus. Nii koosneb näitena 1 toodud pöördumine kahest lausest, millest esimene on esitatud väite ja teine küsimusena. Väitlause tõstab fookusse probleemi (hein on niitmata), kuid implitsiitselt väljendab kirjutaja väite kaudu ka rahulolematust (heina tuleks vähemalt kord kevade-suve jooksul niita) ja osutab soovitavale teole (keegi peaks heina maha niitma). Niisamuti täidab küsilause kolmetist funktsiooni, kuid rõhuasetus on soovitaval teol: kuigi eksplitsiitsel tasandil soovib kodanik, et linnavalitsus annaks teada, millal probleem lahendatakse, siis implitsiitselt ei paku kodanikule huvi mitte konkreetne kuupäev, vaid ta tahab, et probleem saaks lahendatud (keegi hooldaks krunti ehk niidaks heina maha).

Nagu eeltoodust ilmneb, on kaebuste põhieesmärk osutada probleemile, kuid selle abil väljendatakse ka rahulolematust ja nõutakse mingit tegu. Nende teiseste eesmärkide kaudu loob kirjutaja enda ja vahetu suhtluspartneri (linnavalitsuse) vahele tugeva interpersonaalse suhte. Interpersonaalsete suhete võrgustik pole aga üheplaaniline, sest kuna kaebused postitatakse linnavalitsuse avalikku veebiruumi, tuleb kaudse suhtluspartnerina arvesse võtta ka kõiki veebikasutajaid. Metadiskursiivsel tasandil väljendab kirjutaja oma suhtumist suhtluspartnerisse kõige selgemalt interaktsiooniliste tunnuste kaudu.

\section{Kaebuse interaktsioonilised tunnused}

\subsection{Pehmendavad keelendid}

Pehmendavate keelendite abil annab kirjutaja mõista oma valmisolekust arvestada alternatiivseid arvamusi, mistõttu väldib ta otsest suhestumist sisuga: seisukohti edastatakse pigem arvamuse, mitte faktidena, luues seeläbi hea aluse dialoogiks (Hyland 2005b: 52). Vaatlusaluses materjalis eristuvad pehmendavate keelenditena muudest interaktsioonilistest tunnustest viisakussõnad, öeldut nõrgendavad rõhu- ja modaalsõnad ning tingiva kõneviisi vormid. 
Kuigi hea kombe kohaselt alustatakse ametlikku dialoogi viisakusvormeliga, ei kohaldata seda tava ametiasutuste poole pöördumisel. Analüüsitava materjali hulgas leidub küll selliseid pöördumisi, mille alguses kasutatakse sõna Tere(!) (näide 1) või lühendit $L p$ ja lõpus sõna Lugupidamisega, kuid suhtlusolukorra kujundamine viisakusvormelite abil pole kodanikele kuigi omane. Niisamuti leidub vaid üksikuid näiteid sõnade palun, tänan ja aitäh kohta (näited 1 ja 2).

(2) Palun aidake rahurikkuja ( Tartu Häirekeskus) korrale kutsuda või vähemalt vaigistada üle linna ( enamjaolt mõttetult) linnakodanike elukeskkonda reostavad helid! (K4)

Pehmendavate keelendite hulka kuuluvad ka sellised keelevahendid, mis võimaldavad mahendada tugevaid väiteid. Seda ülesannet täidavad määrsõnad miskipärast, tõenäoliselt, ilmselt, ehk ja vist, lisades öeldule ebamäärasust (näide 3). Samuti kuuluvad siia rühma deminutiivse tähendusvarjundiga sõnad üsna, vaid, pea ja natukene (näide 4).

(3) Ka oleks ehk võimalik selle vastu midagi ette võtta? (K39)

(4) Üsna ebameeldiv ostjana sealt väravast siseneda, kunagi ei tea millega pihta võid saada, loobivad lund, jäätükke. (K8)

Modaalverbidest ja muudest modaalsõnadest on esindatud võima, võimalik olema, pidama ja saama (näide 5), mis väljendavad võimalikkust. Neid sõnu kasutatakse tihtipeale tingivas kõneviisis (näide 6), kuid vaatlusaluses materjalis leidub näiteid ka muude tingivas kõneviisis verbide kohta (näide 7).

(5) Kas on võimalik korrale kutsuda valesti parkijaid, et ennetada niigi ohtlikul ristmikul tekkida võivat õnnetust. (K37)

(6) Ehk peaks linn Lepiku tn parkimisele rohkem tähelepanu pöörama, sest meie elu tänu parkijatele keeruliseks muutunud. (K11)

(7) Või kui üritaks ise seda eemaldada,kas siis ei tule mingit probleemi? (K21)

Kuigi pehmendavate keelendite valik on mitmekesine, tõuseb dominantse kategooriana esile vaid tingiv kõneviis. Tingiva kõneviisiga märgitakse sündmuse toimumist irreaalses, praegusel juhul soovitavas maailmas, pehmendades väljendusviisi kategoorilisust ja viisakust (EKG 1993: 34-35). 


\subsection{Võimendavad keelendid}

Erinevalt pehmendavatest keelenditest ei jäta võimendavad keelendid ruumi alternatiivsetele vaadetele, sest kirjutaja võtab sisu suhtes kindla seisukoha (Hyland 2005b: 52). Võimendavad keelendid osutavad ühisele teabele, rühmakuuluvusele ja soovile kaasata lugejaid (Hyland 2005c: 179). Analüüsitavates tekstides kasutatakse võimendamise eesmärgil peamiselt intensiivistavaid määrsõnu, aga ka mentaalset tegevusprotsessi tähistavaid verbe.

Võimendavate keelendite hulgas domineerivad määrsõnad, mis lisavad öeldule intensiivsust. Kodanike lemmiksõnad on väga, juba, ju ja vähemalt, mida vaheldatakse muude olukohaste määrsõnadega, nt sõnadega eriti, kindlalt, niigi, tõsiselt, isegi, ikka, tõesti, ometi, lausa (näide 8). Seevastu intensiivsusprefiksoididest on vaatlusaluses materjalis kasutatud üksnes sõna $\ddot{u} l i$-, sedagi harvadel juhtudel (näide 9). Niisamuti leidub intensiivistavate omadussõnade (näide 10) ning liidepartiklite - $g i$ ja $-k i$ (näide 11) kohta vaid üksikuid näiteid.

(8) See müra on tõesti hirmus ja ma siiralt pean lehepuhureid väga ebaõnnestunud ja sobimatuks tänavate ja parkide puhastamise vahendiks. Parkidesse ei sobi nad kohe üldse mitte, sest parkide eesmärk peaks ju olema puhkus, rohelus jne. (K6)

(9) Täna hommikul oli see ülilibe. (K28)

(10) Absoluutne jääväli, ei mingit soola, liiva ja terve talve. (K17)

(11) Kas on plaanis likvideerida Mathieseni pargis kuivanud lehed või jääbki olukord selliseks,et need pidevalt tuulega Puusepa tn.kõnniteedele lendavad. (K7)

Kirjutatut võimendab ka autori konkreetne seisukohavõtt, mida antakse edasi mentaalset tegevusprotsessi märkivate verbide arvama, kindel olema, teadma ja soovima kaudu. Nii väljendab kodanik näites 12 seisukohta, et häirekeskus ei peaks päevasel ajal linnaelanikke tugeva sireeniga tervitama, lisades vormi arvan abil oma sõnadele kaalu. Ühtlasi aimub sellest seisukohavõtust olukorra muutmise soov.

(12) Arvan, et selline tugev sireen ette ja teated üle linna ei oma mingit tähtsust terve päeva jooksul .. (K4) 


\subsection{Suhtumist väljendavad keelendid}

Suhtumist väljendavad keelendid kajastavad kirjutaja afektiivset, mitte episteemilist suhtumist sisusse: teabe staatuse (nt usaldusväärsuse, õigsuse) asemel on fookuses kirjutaja emotsioonid. Keelevahenditest kasutatakse mitmesuguseid suhtumisverbe, määr- ja omadussõnu, aga suhtumist antakse edasi ka komparatiivivormide, kirjavahemärkide ja teksti paigutuse kaudu. (Hyland 2005b: 53) Siinses allikmaterjalis kannavad suhtumistähendust võrdväärselt omadussõnad ja hüüumärgid.

Kasutatavate omadussõnade rida on pikk, kuid sageduse alusel mingeid dominantseid sõnu esile ei tõuse. Küll aga ühendab enamikku nendest omadussõnadest negatiivne alatoon. Näiteks kuuluvad siia kategooriasse sõnad ebameeldiv, väsitav, saamatu, häiriv, ebaõnnestunud, sobimatu, nahaalne, ohtlik, niru, mõttetu, arusaamatu (näide 13). Seevastu tähenduslikult neutraalne sõnavara täidab vaatlusaluses materjalis marginaalset rolli: vaid öeldistäite positsioonilt leiab sõnad arusaadav, mõistlik ja tähtis (näide 14). Kuigi ka komparatiivivormid on metadiskursiivsete keelevahenditena suhtumise väljendamise teenistuses, pakub analüüsitav allikmaterjal nende kohta vaid ühe näite: lausest 15 ilmneb kodaniku rahulolematus parkimiskorraldusega, mida ta ei pea piisavalt mõistlikuks.

(13) Igal sügisel ja kevadel tuleb seda kohutavat müra taluda, liskas kütuseving ja lendav tolm. Ja see kõik näeb välja väga inetu. (K6)

(14) Arusaaadav on see kui valveauto sõidab majast välja ja vajadusel käivitab sireeni aga miks peab seda mitu minutit ennem teatama üle linna? (K6)

(15) Mida kavatseb linn ette võtta parkimise mõistlikumaks korraldamiseks? (K38)

Peale omadussõnade väljendatakse suhtumist ka hinnanguliste määrsõnadega mõttetult, paljutõotavalt, turvaliselt, häirivalt, normaalselt. Nii näiteks märgib lauses 16 kodanik irooniliselt, et puhuriga töömehe nägemine oli lehekoristuse seisukohast paljutõotav, kuid tulemus jäi saavutamata. Rahulolematusest on kantud ka fraas alla igasugu arvestust (näites 17).

(16) Täna hommikul oli paljutõotavalt 1 töömees puhuriga,kuid seegi kadus (K7)

(17) Praegune olukord eriti sügisvihmadega on alla igasugu arvestust! (K31) 
Näitelause 17 korral ei ilmne suhtumine mitte üksnes fraasist alla igasugu arvestust, vaid ka hüüumärgi kasutusest. Kuigi hüüumärgiga tavatsetakse tähistada hüüd-, käsk- ja soovlauset (EKK 2007: 160), on praeguses allikmaterjalis paigutatud hüüumärk peamiselt väitlause lõppu, olgugi et intonatsioonilised erinevused puuduvad. Sel viisil teisendatakse väide käsuks. Käsku võimendab hüüumärkide sage kasutus (näide 18), samuti mitme hüüumärgi lükkimine järjestikku (näide 19).

(18) Seda [lund] oli seal suures mahus ja väga paksu kihina! Sooviks asjakohast vastust! Hooldatud pole seda kõnniteed mitte kummalgi pool! (K18)

(19) See pargike on aastaid korrastamata, milline sillutis rattaga sõiduks!!!! (K22)

\subsection{Eneseviited}

Teksti luues jätab autor tahes-tahtmata endast maha jälgi, mis ilmnevad seotuses teksti ja lugejaskonnaga. Kõige eksplitsiitsemalt avalduvad need isikuliste (ainsuse ja mitmuse 1. isiku) ning enesekohaste asesõnade kujul. (Hyland 2005b: 53) Eesti keeles lisanduvad nendele keelevahenditele ka verbide ainsuse ja mitmuse 1. pöörde vormid.

Analüüsitulemused näitavad, et kodanikud käsitlevad heakorraprobleeme enesekohasuse prisma kaudu, kasutades selleks peamiselt ainsuse 1. pöörde vormi (näide 20). Harvadel juhtudel võimendatakse minapositsiooni isikulise asesõnaga mina/ma ja omajatäiendiga oma (näide 21).

(20) Helistasin heakorra lühitelefonil, aga sellest abi ei olnud. (K34)

(21) Miks pean ma oma kodulinnas kakerdama jääkonaruste otsas? (K27)

Mina-vormile lisaks väljendavad kodanikud isiklikku seost heakorraprobleemiga meie-vormi kaudu. Meie-rühma kuuluvaina nähakse kas sama asutuse või piirkonna inimesi (näide 22) või linnaelanikke (näide 23), keda heakorraprobleem otseselt mõjutab. Meie-vormi abil vastandatakse end rühmale, mis kannab koondnimetust teised. Enamasti märgitakse sõnaga teised linnavalitsust vm üksust, kelle tegevuse eest linnavalitsus (kaude) vastutab, kuid on ka mõningaid erandeid. Näiteks peetakse lauses 24 meie all silmas nii kodanikke kui ka ametnikke, kuid vaikimisi on tegemist siiski kriitikaga ametnike pihta ja seega vastandusega, sest kritiseeritakse linnavalitsuse menetlustalituse tööd. 
(22) Eelmisel aastal kui meie krundil käis dendroloog siis tema ütles, et puu on väga ohtlik! (K3)

(23) meie tahame ka turvaliselt tööle jõuda. (K17)

(24) On meil ju olemas menetlusteenistus. (K10)

\subsection{Kaasavad keelendid}

Peale pehmendavate, võimendavate ja suhtumist väljendavate keelendite ning eneseviidete esindavad interaktsioonilisi tunnuseid sellised keelendid, millega kaasatakse lugejat. Eesmärk on püüda lugeja tähelepanu, kasutades isikulisi asesõnu, või kaasata lugejat diskursuseosalisena, pöördudes tema poole küsimuste, käskiva kõneviisi ja kohustuslikkust väljendavate modaalverbide vormis (Hyland 2005b: 53-54). Vaatlusalustes kaebustes eelistatakse kahesuguseid keelevahendeid: küsimusi ja isikulisi asesõnu.

Küsimuste esitamine on peamine viis pöörduda ametiasutuse poole. Kodanike vaieldamatud lemmikud on kas-küsimused (näide 25), kuid ametnikke pommitatakse ka miks-küsimustega (näide 26). Niisamuti tuntakse huvi heakorraprobleemi lahendamise aja vastu, mida tõendavad sõnadega kuna, millal ja kaua algavad küsimused (näide 27). Seejuures on just küsisõnad küsimuse tunnuseks, sest allikmaterjal sisaldab ka küsimärgistamata jäetud küsimusi (näide 28), samuti kaudseid küsimusi (näide 29).

(25) Kas linnavalitsus ei näe või ei soovi antud probleemiga tegeleda? (K23)

(26) Miks ma pean jälle sellest kohast kirjutama ja tõdema kui saamatu on Tartu linnavõim????? (K35)

(27) Millal hakkavad nendel kruntidel kehtima linna heakorrareeglid? (K32)

(28) Miks on Era tänava kõnniteed puhastamata. (K19)

(29) Palun teatage, millal tänav korda tehakse. (K15)

Teine peamine viis ametiasutuse poole pöörduda on kasutada isikulist asesõna teie/te ja sellele vastavat verbivormi (näide 30). Kuna kaebus on esitatud veebiliidese kaudu ja kodanik ei tea, kes tema pöördumisele vastab, siis mitmuse 3. isiku vormide alternatiivina märgitakse pöördumise adressaati ka sõnadega linn, Tartu linnavõim, linnavalitsus ja linnavalitsuse ametnik (näited 25 ja 26).

(30) Seega, kas te võiksite kaaluda lehepuhurite kasutamise piiramist või keelamist - vähemalt kesklinnas ja Toomel? (K6) 
Kuigi Hylandi (2005b: 54) järgi kuuluvad kaasavate keelendite hulka kohustuslikkust väljendavad modaalverbid, on need kaebustes vaid tagasihoidlikult esindatud. Üksikuid näiteid leidub modaalverbide pidama ja tulema kohta (näide 31). Niisamuti on käskiv kõneviis teisejärguline viis kaasata lugejat (vt näide 32, esimene ja viimane lause).

(31) Tegevusloa väljastamisel tuleb vaadata ja ette näha ka tekkivaid probleeme parkimise osas . (K35)

\section{Kokkuvõttev arutelu}

Tartu linnavalitsuse veebilehe rubriigi „Ametnik vastab“ eesmärk on pakkuda kodanikele võimalust küsida ametnikelt küsimusi Tartu linnaga seotud probleemide kohta. Kuna kodanikud ei piirdu üksnes probleemist teavitamisega, vaid kasutavad pöördumisi ka muudel eesmärkidel, muudab see suhtluse ametkonnaga tähenduslikult mitmekihiliseks. Olukorrale lisab pinevust seegi, et kodanikud peavad osa probleemide (nt heakorraprobleemide) eest vastutavaks just linnavalitsust, kelle võimuses on samal ajal ka probleemset olukorda muuta.

Linnavalitsusele esitatud kaebuste sisestruktuuri analüüsist ilmneb kolm kohustuslikku retoorilist käiku: probleemile osutamine, rahulolematuse väljendamine ja soovitava teo nimetamine. Need käigud on omavahel tihedalt põimunud, nii et üks pindstruktuuri tekstiosa võib korraga täita mitut eesmärki. Seejuures ei pööra kodanikud ametniku poole pöördudes eritähelepanu suhtlusolukorra kujundamisele viisakussõnade abil või tausta tutvustamisele, vaid keskenduvad ainiti probleemile, esitades seda sageli emotsionaalses võtmes. Kui taustteabe pakkumine ei olegi alati asjakohane, siis viisakusavaldusi pöördumise alguses ja lõpus võib pidada ametisuhtluse vaiketunnusteks. Nende puudumist saab seletada kaheti. Esiteks, kuna heakorraprobleemid, eriti kui neid seostatakse linnavalitsuse tegematajätmistega, kütavad kirgi, siis ei pea kodanikud nimme vajalikuks väljendada ametiasutuse suhtes lugupidamist. Teiseks võib viisakusvormelitest loobumine olla seotud veebivormi kui formaadiga: kuna väli, kuhu sisestatakse tekst, on võrdlemisi väike, võib see tingida otsuse piirduda üksnes sisuosaga, liiatigi nõutakse kontaktandmete esitamist väljaspool tekstivälja.

Peale sisestruktuuri puudutab mitmetähenduslikkus ka metadiskursuse tasandit. Kuna mõned metadiskursiivsed keelevahendid täidavad mitut 
funktsiooni (Vande Kopple 2012: 40; Flowerdew 2015: 23), ähmastab see kategooriatevahelist piiri. Näiteks võib olenevalt lausest kuuluda sõna võimalik (ingl possible) nii pehmendavate kui ka suhtumist väljendavate keelendite sekka (Hyland 2017: 17). Liigitusprobleem tuleb iseäranis selgelt esile mitmesõnaliste analüüsiüksuste korral, sest eraldi võetuna võivad need esindada eri kategooriaid. Üks võimalikke lahendusi on seada funktsioonid tähtsuse järjekorda, mis võimaldab määrata kategooriaid analüüsiüksuse põhifunktsiooni alusel. (Flowerdew 2015: 24) Seesama põhimõte on olnud ka siinse analüüsi lähtekohaks, mis avaldub kõige kujukamalt küsimuste kui metadiskursiivsete tunnuste liigitamisel. Kuna küsimused kuuluvad traditsiooniliselt kaasavate keelendite hulka (Hyland 2005b: 54), siis olen kaasamise määranud nende esmaseks funktsiooniks, kuid möönan samas, et küsimuste kaudu väljendavad kirjutajad ka oma suhtumist. Selline mitmefunktsioonilisus annab alust väita, et metadiskursiivsete tunnuste puhtkvantitatiivseks analüüsiks tuleb analüüsiüksusi hoolikalt valida või täiendada kvantitatiivset analüüsi kvalitatiivsega.

Kaebuste metadiskursiivsete tunnuste analüüsist selgub, et heakorraprobleemid kutsuvad kodanikes esile emotsioonipuhangu. Kuigi aeg-ajalt pehmendatakse öeldut mitmesuguste keelevahendite, sealhulgas tingiva kõneviisi abil, domineerib kaebustes siiski negatiivne foon. Rahulolematus avaldub peaasjalikult negatiivsete omadussõnade kaudu, mida võimendatakse omakorda määrsõnadega, nt väga inetu, eriti hull. Emotsioonide väljendamine ei piirdu aga üksnes sõnatasandiga, vaid ka lausetasand on emotsioonidest tulvil. Lauselõpumärkidest kannavad emotsionaalset laengut hüüumärgid, millega tavatsetakse markeerida väitlauseid, soovides seeläbi suurendada väite mõjukust. Hüüumärkide kasutuses peegeldub ka kirjutaja meelepaha ja kärsitus, sest nii mõnelgi juhul liialdatakse jutumärkidega, pannes need mitme järjestikuse lause lõppu või lõpetades lause mitme jutumärgiga.

Hüüumärgistatud lausete kõrval on kaebustes rohkesti ka küsimärgistatud lauseid. Küsimused on kodanike lemmikviis pöörduda probleemide korral ametiasutuse poole. Ühelt poolt dikteerib küsimusevormi linnavalitsuse veebilehe märge „Ootame siia rubriiki küsimusi probleemide kohta", teisalt aga võib küsimuste sagedane kasutus tuleneda nende mitmefunktsioonilisest olemusest, sest peale esmase eesmärgi - osutada probleemile - võimaldavad küsimused täita muidki eesmärke, sh väljendada negatiivseid emotsioone. 
Interaktsiooniliste keelevahendite hulka kuuluvad samuti keelendid, mille abil osutatakse tekstis iseendale ja lugejale. Üldise tendentsina võib täheldada, et kodanikud pöörduvad ametiasutuse poole eeskätt enda nimel, edastades seeläbi tugeva minasõnumi. Seevastu ametiasutuse kõnetamisel on võrdväärselt kasutusel nii teie-vorm kui ka asutust märkivad nimisõnad (nt linnavalitsus, linnavõim). Selline esitusviis on ootuspärane, sest kaebusele reageerib ametnik, kes esindab kas mõnd ametiasutuse allüksust või ametiasutust tervikuna.

Kuna eeltoodud analüüsist ilmneb, et probleemile osutamise ja rahulolematuse väljendamise kaudu soovib kodanik ametiasutuselt konkreetse teo tegemist, siis võib vaatlusalused kaebused liigitada instruktiivse tekstitüübi alla (vt Werlich 1976). Kuigi tavaliselt on instruktiivse tekstitüübi tunnused käskiv kõneviis, kohustuslikkust väljendavad modaalverbid ja $d a$-tegevusnime vormid, siis vaatlusalustes tekstides avaldub instruktiivsus enamasti hoopis muude metadiskursiivsete keelevahendite, eelkõige küsimuste kujul. Ainuüksi metadiskursusega instruktiivsus ei piirdu, sest metadiskursiivsed tunnused ei kata abstraktsema tasandi keelenähtusi, sh irooniat, mis samuti annab aimu soovitavast teost. Nii on näite 32 ava- ja lõpulauses kasutatud käskivat kõneviisi, millega kohustatakse ametnikku otsesõnu, kuid nimetades iroonitsevalt pargiteed rattasõidu jaoks sobivaks sillutiseks või kõnniteed haruldaseks lõiguks ja roomajate kiilteeks, väljendab kodanik oma rahulolematust olukorraga, vaikimisi ka soovi, et linnavalitsus lahendaks probleemi.

(32)Palun tehke ometi korda kaubamaja esine park. Kõnnime sealt läbi (päevas 1000 inimest) mööda libedat ja konarlikku teed.See pargike on aastaid korrastamata, milline sillutis rattaga sõiduks!!!! Natukene piinlik juba.

Ja teine haruldane lõik on Uue tänava ja Kalda tee vaheline jalakäijate kiiltee( see on ju roomajate kiiltee.Absoluutne jääväli, ei mingit soola, liiva ja terve talve. Sealt lähevad ju inimesed bussi peale, lapsed kooli. Ei mingit valgustust.Tean, et selle probleemiga on pöördutud teie poole juba mitmendat korda( ka mina). Tule taevas appi, tulge ometi raekoja platsist kaugemale ka... meie tahame ka turvaliselt tööle jõuda.? (K17)

Seega on kodanikud kaebuste esitamisel oma keelekasutuses üsna vabad. Pidamata vajalikuks kujundada suhtlussituatsiooni viisakusvormelite abil, anda ülevaadet taustast või kirjeldada üksikasjalikult olukorda, keskendutakse neid vaevavale probleemile. Seejuures ei hoia 
kodanikud oma tundeid vaka all, vaid on varmad väljendama negatiivseid emotsioone, laenates selleks asjakohaseid väljendusvahendeid eri keeletasanditelt.

\section{Kirjandus}

Abdi, Reza 2002. Interpersonal metadiscourse: an indicator of interaction and identity. - Discourse Studies 4 (2), 139-145.

Al-Momani, Kawakib Radwan 2014. Strategies of persuasion in letters of complaint in academic context: the case of Jordanian university students' complaints. - Studies 16 (6), 705-728.

Bhatia, Vijay K. 2002. Applied genre analysis: a multiperspective model. Ibérica 4, 3-19. http://www.aelfe.org/documents/text4-Bhatia.pdf (06.01.2018).

Bruce, Ian 2008. Academic Writing and Genre. A Systematic Analysis. London, New York: Continuum.

EKG 1993 = Mati Erelt, Reet Kasik, Helle Metslang, Henno Rajandi, Kristiina Ross, Henn Saari, Kaja Tael, Silvi Vare. Eesti keele grammatika. II. Süntaks. Lisa: Kiri. Peatoim. Mati Erelt, toim. Tiiu Erelt, Henn Saari, Ülle Viks. Tallinn: Eesti Teaduste Akadeemia Keele ja Kirjanduse Instituut.

EKK 2007 = Mati Erelt, Tiiu Erelt, Kristiina Ross. Eesti keele käsiraamat. Kolmas, täiendatud trükk. Tallinn: Eesti Keele Sihtasutus. http://www.eki. ee/books/ekk09/index.php?id=84\&p=2\&p1=11 (06.01.2018).

Flowerdew, John 2015. Revisiting metadiscourse: conceptual and methodological issues concerning signalling nouns. - Ibérica 29, 15-34. http://www. aelfe.org/documents/03 IBERICA_29.pdf (06.01.2018).

Henry, Alex, Debbie G. E. Ho 2010. The act of complaining in Brunei-Then and now. - Journal of Pragmatics 42 (3), 840-855. doi:10.1016/j. pragma.2009.08.011.

Hooi, Chee Mei, Munir Shuib 2014. An analysis of hedging devices in complaint business letters. - GEMA Online ${ }^{\circledR}$ Journal of Language Studies 14 (3), 123-142. http://ejournal.ukm.my/gema/article/view/7105/3255 (06.01.2018).

Hyland, Ken 2003. Genre-based pedagogies: a social response to process. Journal of Second Language Writing 12 (1), 17-29. doi:10.1016/S10603743(02)00124-8.

Hyland, Ken 2005a. Metadiscourse. The International Encyclopedia of Language and Social Interaction. Wiley Online Library. http://onlinelibrary.wiley. com/doi/10.1002/9781118611463.wbielsi003/full (06.01.2018).

Hyland, Ken 2005b. Metadiscourse. Exploring Interaction in Writing. Continuum Discourse Series. London, New York: Continuum. 
Hyland, Ken 2005c. Stance and engagement: a model of interaction in academic discourse. - Discourse Studies 7 (2), 173-192. doi:10.1177/ 1461445605050365 .

Hyland, Ken 2007. Genre and Second Language Writing. Michigan: The University of Michigan Press.

Hyland, Ken 2017. Metadiscourse: what is it and where is it going? - Journal of Pragmatics 113, 16-29. doi:10.1016/j.pragma.2017.03.007.

Hyon, Sunny 2017. Introducing Genre and English for Specific Purposes. Oxon, New York: Routledge.

Olhstain, Elite, Liora Weinbach 1993. Interlanguage features of the speech act of complaining. - Interlanguage Pragmatics. Eds. Gabriele Kasper, Shoshana Blum-Kulka. New York: Oxford University Press, 108-122.

Schaefer, Kelly A. 2010. Response-to-complaint letter as a rhetorical genre. IEEE Transactions on Professional Communication 53 (2), 158-163. doi:10.1109/TPC.2010.2046089.

Swales, John M. 1990. Genre Analysis. English in Academic and Research Settings. The Cambridge Applied Linguistics Series. Cambridge: Cambridge University Press.

Swales, John M. 2016. Configuring image and context: writing 'about' pictures. English for Specific Purposes 41, 22-35.

Tardy, Christine M., John M. Swales 2014. Genre analysis. - Pragmatics of Discourse. Eds. Claus P. Schneider, Anne Barron. Handbooks of Pragmatics. Berlin, Boston: De Gruyter Mouton, 165-188. http://dx.doi. org/10.1515/9783110214406-007.

Trosborg, Anna 1995. Interlanguage Pragmatics. Requests, Complaints, and Apologies. (= Studies in Anthropological Linguistics 7.) Berlin, New York: Walter de Gruyter. http://dx.doi.org/10.1515/9783110885286.

Vande Kopple, William J. 1985. Some exploratory discourse on metadiscourse. - College Composition and Communication 36 (1), 82-93. doi: $10.2307 / 357609$.

Vande Kopple, William J. 2012. The importance of studying metadiscourse. Applied Research on English Language 1 (2), 37-44.

Werlich, Egon 1976. A Text Grammar of English. Heidelberg: Quelle \& Meyer. Ädel, Annelie, Anna Mauranen 2010. Metadiscourse: diverse and divided perspectives. - Nordic Journal of English Studies 9 (2), 1-11. 


\title{
Good heavens, why won't you look a bit further from the Town Hall square!: The strategic choices used by citizens in texts written to authorities
}

\author{
RIINA REINSALU
}

One of the preconditions of a well-functioning information society is dialogic communication between citizens and officials. For this, agencies provide several options, including the chance to indicate problems via a web form. The objective of the article is to clarify which are the strategic text choices of citizens when they contact officials with a complaint. In other words, the article focuses on which obligatory and selective moves comprise the internal structure of the complaints of the survey subjects and which metadiscursive linguistic devices are used for conveying the content.

The source material of the article is 40 complaints ( 2659 words in total) submitted by citizen to the Tartu city government from 2013-2017. The complaints are taken from the public webpage section "Official answers" and concern the city's maintenance issues. Dealing with maintenance issues brings an intrigue into the communication, as the authorities are considered to be directly or indirectly liable for the problem. However, as it is in the power of the authorities to remedy the situation, it may be presumed that a citizen must be careful when making strategic choices in texts, carefully selecting the way of addressing the authorities.

Applying the genre analysis of Swales (1990) when analysing the source material, it appears that the internal structure of the complaint consists of three compulsory moves - pointing out the problem, expressing discontent and naming the recommended activity - which are closely intertwined. Selective moves, dealing with starting and ending the communication, introducing the background and describing the situation, are secondary compared to the general objective of the complaint.

Internal structure moves in texts are realised as multiple metatextual features, of which Hyland's (2005b) linguistic devices included in the interaction features in the framework of metadiscourse are of interest in the context of this article. Although from time to time citizens consider it necessary to mitigate their text with hedges, a negative perception still dominates in the complaints, conveyed through attitude markers and boosters. Discontent is expressed not only in words, but also through emotions. The punctuation marks that carry an emotional charge 
are exclamation marks as well as question marks, which are traditionally considered engagement markers, and in some cases these also meet the same objective. In the latter case, the citizen is primarily speaking for himself/herself, not for a group, using the first person, which represents the category of self-mentions.

Keywords: complaint, institutional communication, text type, metadiscourse, genre analysis, Estonian

\author{
Riina Reinsalu \\ eesti ja üldkeeleteaduse instituut \\ Tartu Ülikool \\ Jakobi 2 \\ 51014 Tartu \\ riina.reinsalu@ut.ee
}

